\title{
Review on NiO thin film as hole transport layer in perovskite solar cell
}

\author{
Kamal Bhujel ${ }^{1,2} *$, Suman Rai ${ }^{2}$, Ningthoujam Surajkumar Singh ${ }^{1}$ \\ ${ }^{1}$ Physical Sciences Research Center, Pachhunga University College, Aizawl, 796001, India \\ ${ }^{2}$ Laser and Photonics Laboratory, Department of Physics, Mizoram University, Aizawl, 796004, India \\ *kamalaawaz@gmail.com
}

DOI 10.17586/2220-8054-2021-12-6-703-710

\begin{abstract}
The saturation in increasing the power conversion efficiency (PCE) of silicon-based solar cells made researchers around world to look for the alternatives. An alternative solar cell would possess some basic requirements like cost effectiveness, reproducible, durable (stability), non-toxicity and higher efficiency. Perovskite solar cell (PSC) opened the new realm of hope for this alternative, consisting of perovskite absorber sandwich between the hole transport layer (HTL) and the electron transport layer (ETL). Good performance of PSCs can be achieved by optimizing many parameters of the components of PSC for obtaining the highest PCE. Among them, the HTL also plays a very vital role. Previously, organic poly (3,4-ethylenedioxythiophene):poly (styrene sulfonic acid) PEDOT:PSS was being widely used as the HTL in PSCs, but due to its hygroscopic nature and acidic properties, it lowered the stability and the life time of the PSCs. Later it was replaced mostly by NiO, a p-type transparent conducting oxide (TCO) enhancing the PCE of PSCs. Its excellent stability and electrical/optical properties attracted the interest of many researchers. Different types of PSCs used $\mathrm{NiO}$ thin films prepared from different synthesis routes and obtained variation in efficiency of PSCs. Different parameters of $\mathrm{NiO}$ thin films like thickness, annealing temperature (AT) and duration, precursor combinations and more in synthesis processes, have a significant role in optimizing the PCE. Though there are many routes for obtaining NiO thin film, here we are trying to focus more on sol-gel method, as this route is very cost effective and employs basic equipment. Its evolution, present status and the future perspectives will also be discussed.
\end{abstract}

Keywords: power conversion efficiency, organic photovoltaic device, annealing temperature, sol-gel method.

Received: 19 December 2020

Revised: 4 April 2021

Final revision: 3 December 2021

\section{Introduction}

In human civilization, energy has played an important role in societal evolution. The trend of social development and many more dimensions of human civilization depend upon the availability of the energy resources and its rational utilization. The limited sources of energy materials and the ever-increasing demand for energy create a situation of scarcity over the resources. Sources of energy materials directly affect the global economy. So, the whole world is concerned about the permanent solution of the energy crisis.

Ultimately researchers are interested in solar energy. Solar energy can be converted into electrical energy and can be used as alternative to conventional carbon-based sources of energy. Gradual development took place from the initial discovery of the solar photovoltaic effect in 1839 by French Scientist Edmond Becquerel [1]. Since the world's first Photovoltaic solar cell by Chapin et al. [3], solar cells have been based on silicon, selenium, cadmium, copper, dye-sensitized photochemical cell, thin film solar cell based on different materials with solar storage [2], to perovskite solar cells at present. Perovskite based solar cell shave recently reached an efficiency $>25 \%$ [4].

Many elements and compounds have photovoltaic properties which allow conversion of solar energy into electrical energy. Historically, the silicon-based solar cells have gained the popularity, but due to their limited efficiency, scientists are finding alternatives. The perovskite solar cell is currently popular. Lead-based perovskite solar cells have almost attained the efficiency of the silicon-based solar cells. As $\mathrm{Pb}$ is toxic to the environment, its commercialization became the hurdle in the development of high efficiency solar cell. So, now an alternative to the Pb-PSCs is currently a topic of research interest. Pb-free PSCs seem to be promising alternatives for replacing the conventional Si-based solar cells [5].

\section{Perovskite and $\mathrm{NiO}$ in the solar cell}

Perovskite is a crystal named after the Russian mineralogist Lev Perovski. Its crystal structure generalized as $\mathrm{ABX}_{3}$ form, in which $\mathrm{A}$ is a $2+$ metal cation, $\mathrm{B}$ is a $4+$ metal cation and $\mathrm{X}$ is a $2-$ oxygen anion or halogens. Common examples are $\mathrm{CaTiO}_{3}, \mathrm{BaTiO}_{3}$, and $\mathrm{CsSnI}_{3}$, etc. Gradually, many more perovskite materials were discovered and halide perovskite, organic perovskite, mixed organic-inorganic perovskite, double and triple perovskite materials were also introduced. In 2009, the first perovskite based Dye Sensitized Solar Cell (DSSC) was reported by Kojima 
et al. [6] and first solid state solar cell based on perovskite was reported by Kim et al. [7]. Currently, the organo-leadhalide perovskite has achieved the highest efficiency in comparison to the Si-Solar Cells. $\mathrm{Pb}$ is mostly replaced by $\mathrm{Sn}$ and achieved the comparable efficiency. Since, the oxide of $\mathrm{Sn}$ is unstable in ambient environment; it has become a serious issue to be resolved. Inorganic and double perovskites are also an other possibility for research.

The general architecture of the thin film based PSCs has a multi-layer structure of its components like electrodes, ETL, perovskite absorbers, HTL and back contact. Perovskite absorbers are mainly sandwiched between the HTL and ETL (Fig. 1) [42]. The variation in the ETL and HTL has shown improvement in increasing the efficiency of

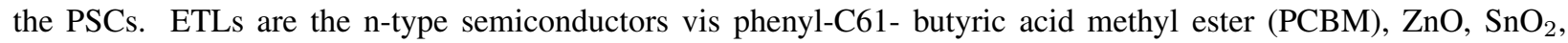
$\mathrm{TiO}_{2}$, etc. and HTLs are the p-type semiconductors namely, 2,2',7,7'-tetrakis(N,N-pdimethoxyphenylamino)-9,9'spirobifluorene (Spiro-OMeTAD), poly(3,4-ethylenedioxythiophene)/poly(styrenesulfonicacid) (PEDOT:PSS), $\mathrm{NiO}_{x}$, CuSCN, etc. Previously the organic HTL PEDOT:PSS was very common in PSCs, but due to its hygroscopic and poor electron blocking nature, significant degradation in PCE occurred. If the electrons are not blocked properly, then the recombination at the interface layer will be increased, leading to low cell efficiency [8]. PEDOT:PSS also has an acidic nature. Transport materials need to be transparent, able to block the electron, should possess Ohmic contact with the electrodes and good stability. $\mathrm{NiO}$ thin film was the next candidate with all these properties. It was found that the inorganic materials provide good stability and carrier mobility [10].
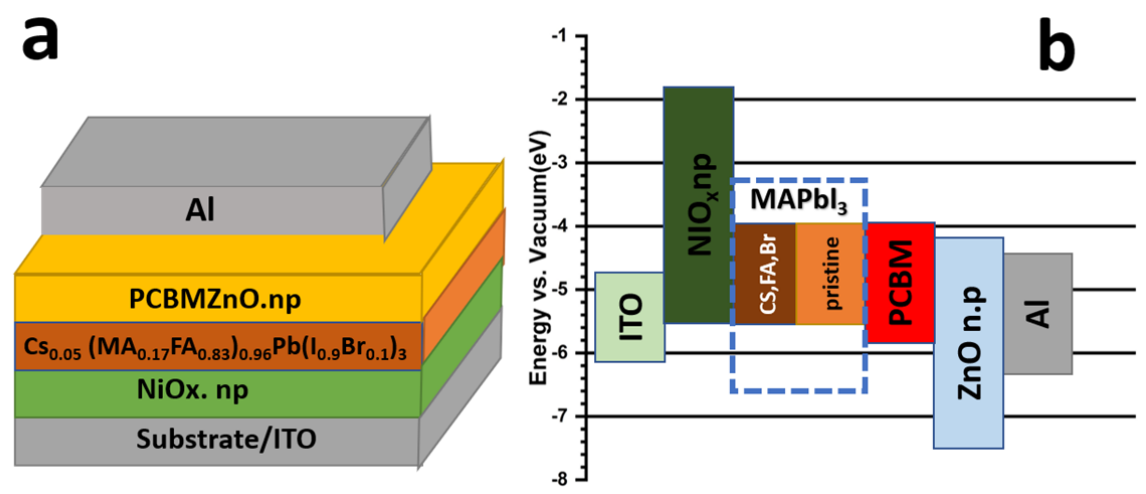

FIG. 1. a) Typical device architecture of the inverted planar PSCs. b) Energy levels of layers in the stack (Copyright permission taken from ref. [42])

Electron-hole pairs $(\mathrm{E}-\mathrm{H})$ are generated when light is incident upon the absorber. To extract the E-H and to transport to the corresponding electrodes, ETL and HTL are required respectively. In general, PSCs, ETL is deposited on the TCO (mainly FTO/ITO) followed by the perovskite absorber. HTL is deposited above the absorber to extract the holes efficiently. On the top of the hole, metal layer of silver $(\mathrm{Ag})$ or gold $(\mathrm{Au})$ is deposited (TCO/ETL/Perovskite/HTL/Ag) and in inverted configuration, just the position of HTL and ETL are interchanged (TCO/HTL/Perovskite/ETL/Ag). Previously, the ETL and HTL were incorporated with some meso-porous layers also.

This review mainly concentrates on development in synthesis process of $\mathrm{NiO}$ thin film for the application as HTL in PSCs. With the introduction of NiO as HTL in PSCs, many possibilities have been seen in improving the efficiency of the PSCs. NiO thin films have been synthesized varying many synthesis routes and parameters like thickness, different precursors or solvents [9], annealing time and temperature and influenced the properties of the solar cell. There are many routes for depositing the $\mathrm{NiO}$ thin film, including: sol-gel route (Fig. 2) [10,11], direct spin coating from pre-synthesized nanocrystals [12], combustion method [13], electrodeposition [14], sputtering [15], pulsed laser deposition (PLD) [16], atomic layer deposition (ALD) [17], spray pyrolysis [18], chemical precipitation methods [19] and many more have been used for the thin film deposition.

Nickel oxide $(\mathrm{NiO})$ has a basic cubic structure with the space group $\mathrm{Fm} 3 \mathrm{M}$ which is similar to that of $\mathrm{NaCl}$. Its lattice parameter is $0.4173 \mathrm{~nm} \mathrm{[20].} \mathrm{NiO}$ is a wide bandgap material having the band gap in the range of $3.6-4.0 \mathrm{eV}$ with the work function of $5.4 \mathrm{eV}$. It is a highly transparent nano thin film enabling it to be a good p-type TCO [21,22].

\section{Literature survey}

Jimenze et al. synthesized $\mathrm{NiO}$ thin film via a dip-coating sol-gel route using Ni-acetate as precursor. They studied the effect of AT on crystal structure and found the films to be amorphous when annealed between $175-250{ }^{\circ} \mathrm{C}$ and above $250{ }^{\circ} \mathrm{C}$ it was crystalline with a good surface homogeneity. They found the dependency of electrical conductivity with the thickness in the range of $2 \times 10^{-5}$ to $6.5 \times 10^{-3}(\Omega \cdot \mathrm{cm})^{-1}$ and similarly the energy band gap $E_{g}$ was from 


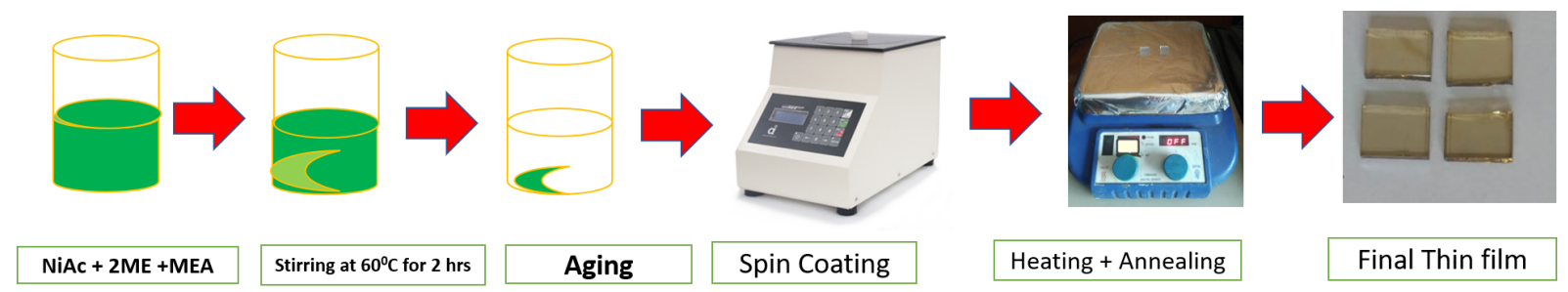

FIG. 2. Schematic sol-gel route for NiO thin film synthesis following the method of ref [11]

3.9 to $3.8 \mathrm{eV}$ for the corresponding film thickness varying from 49 to $191.8 \mathrm{~nm}$. The transmittance of films decreased with increased thickness and the films with thickness $>100 \mathrm{~nm}$ had very low optical transmittance. Slower growth rate resulted in good morphology and uniform homogeneity with increasing electrical conductivity [23]. The effect of precursor on the grain size of the thin film was observed as $2-3 \mathrm{~nm}$ in case of Ni-sulfate precursor than Ni-acetate (average $5 \mathrm{~nm}$ ) via $\mathrm{SG}$ route [24]. The electrical resistivity decreased with an increase in temperature (semiconductor behavior) and thickness was calibrated graphically for chemical bath-deposited films [25]. AT changes the surface roughness and the crystal structure. At an AT up to $300{ }^{\circ} \mathrm{C}$ good surface morphology was not observed, and it was found to be amorphous in nature. However, above $300{ }^{\circ} \mathrm{C}$, the surface roughness also started improving with the proper crystal structure. The correlation between the deposition parameters and optical properties of the NiO thin film was also established. The AT and dipping speed also affected the refractive index and the extinction coefficient of the films [26]. Ghamadi et al. prepared thin film by the SGSC method using Ni-Ac as precursor with an optimum AT of $600{ }^{\circ} \mathrm{C}$. Their study showed that the volume energy loss is greater than the surface energy loss at all incident photon energies. The optical band gap was $3.44 \mathrm{eV}$. They used single electronic oscillator mode to obtain the values for the oscillator strength, oscillator energy. They also calculated dielectric and refractive index of the film with values of 4.04 and 2.01 respectively. The value of third order susceptibility was estimated using Frumer model as $1.62 \times 10^{-13}$ esu [27]. Patil et al. synthesized $\mathrm{NiO}$ nanopowder via chemical precipitation route using nickel acetate as a precursor. Further, the $\mathrm{NiO}$ powder was mixed with $\mathrm{m}$-cresol and prepared as a thin film using a spin-coater. They observed the decrease in band gap energy from 3.86 to $3.47 \mathrm{eV}$ and increase in electrical conductivity from $10^{-4}$ to $10^{-2}(\Omega \cdot \mathrm{cm})^{-1}$ after annealing the $\mathrm{NiO}$ films from 400 to $700{ }^{\circ} \mathrm{C}$ [28]. With increasing AT from $400-700{ }^{\circ} \mathrm{C}$ there was an increase in mean grain size. Increasing the grain size $(40-60 \mathrm{~nm})$ caused a decrease in the grain boundary density of a film and decrease in scattering of carriers at grain boundaries. With an increase in AT, the absorption coefficient of the film also increased. This could be assumed due to increase in the density of states of holes with increase in AT [29]. Annealing $\left(600{ }^{\circ} \mathrm{C}\right.$ ) in different environments (air and $\mathrm{N}_{2}$ ) showed that grain size increased with the increased in number of layers for annealing at aerobic environment but in $\mathrm{N}_{2}$ environment there was a decrease in grain size. Even the optical band gap energy decreased from 3.76 to $3.52 \mathrm{eV}$ and 3.75 to $3.49 \mathrm{eV}$ annealed in air and $\mathrm{N}_{2}$ respectively. The resistivity of air annealed film was more than that of $\mathrm{N}_{2}$ as $900 \times 10^{3}$ and $40 \Omega \cdot \mathrm{cm}$ respectively. Aerobic annealing leads to production of larger grains and better crystalline structure with lower oxygen vacancies, which can be the predominant factor of conductivity with higher resistivity [10]. Thermal analysis showed that below an AT of $400{ }^{\circ} \mathrm{C}$ there was continuous decomposition and weight loss and after reaching $400{ }^{\circ} \mathrm{C}$, the weight loss became constant, leading to the formation of $\mathrm{NiO}$ crystal [30]. Annealing increased the surface roughness and it might be due to the fact that the annealing process would enlarge the NiO particle sizes [31]. Sahoo et al. showed the influence of AT on morphological, optical and electrical properties of SGSC synthesized NiO thin film. AT affected the current at light and dark mode from 9.9 to $3.3 \mathrm{~mA}$ and 7.9 to $3.6 \mathrm{~mA}$ respectively [11]. Kayani et al. synthesized NiO powder via SG route varying the AT from 400 to $1000{ }^{\circ} \mathrm{C}$. The crystalline sizes increased with increased AT from 12 to $32 \mathrm{~nm}$ from $400-1000{ }^{\circ} \mathrm{C}$ respectively. The dislocation density decreased from $6.5 \times 10^{-3}$ to $2.3 \times 10^{-3} \mathrm{~nm}^{-2}$ with an increase in AT. The transmittance decreased with increasing AT, but the band gap increased from 3.02 to $3.14 \mathrm{eV}$. This increase in the band gap may be due to an increase in the defect levels. When magnetic field was applied on $\mathrm{NiO}$ nanoparticles the magnetization showed a more or less linear dependence. Therefore, NiO nanoparticles showed paramagnetic behavior. $\mathrm{NiO}$ also showed ferromagnetic behavior above the critical diameter of $55 \mathrm{~nm}$, below which, the nanoparticles became single magnetic domains [32]. The transmittance decreased with increasing the thickness but couldn't find the proper correlation of reflectance with the thickness. Band gap energy increased from 3.87 to $3.94 \mathrm{eV}$ as thickness increased from 124 to $166 \mathrm{~nm}$. Electrical conductivity which was increased from $7.94 \times 10^{-3}$ to $27.89 \times 10^{-3}(\Omega \cdot \mathrm{cm})^{-1}$ when film thickness increased from 124 to $137 \mathrm{~nm}$ but again decreased at $145 \mathrm{~nm}$ and at $166 \mathrm{~nm}$ showed a good electrical conductivity with $84 \times 10^{-3}(\Omega \cdot \mathrm{cm})^{-1}$ [33]. Average crystalline size increased with 
increasing AT whereas dislocation density decreased. Annealing reduced the lattice defects of the film and increased the crystalline quality by modifying the periodic arrangement of atoms in the crystal lattice [34].

\section{4. $\mathrm{NiO}$ as hole transport layer}

HTL serves as an electron blocking layer in bulk heterojunction (BHJ) solar cell. Previously used HTL PEDOT:PSS degraded so early and had a limited performance. Aqueous solution of PEDOT:PSS was highly acidic in nature with $\mathrm{pH}$ 1.2. Due to its hygroscopic nature, moisture may get absorbed leading to proton release and anode corrosion [8]. As a result, it leads to the degradation of device, lowering lifetime and overall performance of the device. For an ideal candidate to be used as HTL, it should have $E_{g}>3 \mathrm{eV}$, p-type transparent conducting material, it should be chemically stable and possess good conductivity.

Steirer et al. introduced $\mathrm{NiO}$ thin film replacing the PEDOT:PSS in OPV. The NiO thin film was deposited by a solution based Ni-organic inkjet technique. Although the work function of $\mathrm{NiO}$ was tailored by $\mathrm{O}_{2}$-plasma treatment but the real effect was not understood properly. Thicker films produced uniform devices with lower open-circuit voltage $\left(V_{o c}\right)$, lower short-circuit current density $\left(J_{s c}\right)$ and higher series resistance $\left(R_{s}\right)$. Thinner films failed to produce uniform device on a substrate causing inconsistent performance, perhaps due to incomplete surface coverage. But the optimum thickness varied from device to device. The device ITO/NiO/P3HT:PCBM/Ca/Al, attained the PCE of $3.6 \%$. In comparison, the performance of $\mathrm{NiO}$ was as good as that of PEDOT:PSS [16]. Films synthesized via PLD technique was applied in BHJ solar cell improved the performance with work function of $\sim 5.3 \mathrm{eV}$, optical transmittance of $>80 \%$. The problem in forming good Ohmic contact caused lowering of efficiency to some extent [35]. Hsu et al. demonstrated, for the first time, the fabrication of uniform, defect-free, and conformal $\mathrm{NiO}$ ultra-thin films for use as HTL in BHJ polymer solar cell via ALD optimizing its processing parameters. ALD offers unparalleled advantages owing to its unique capabilities, including defect-free deposition, complete and uniform coverage over large-area/highaspect-ratio surface features, precise control over deposited thickness, and low deposition temperatures. Thickness was optimized and $4 \mathrm{~nm}$ seemed to be the optimum one giving comparable PCE of $3.38 \%$ comparable to PEDOT:PSS [17]. You et al. improved the air stability of the PSC using solution processed NiO as HTL. The maximum PCE obtained was $14.6 \pm 1.5 \%$ with device architecture glass/ITO/NiO $/ \mathrm{CH}_{3} \mathrm{NH}_{3} \mathrm{PbI}_{3} / \mathrm{PCBM} / \mathrm{Al}$. The crystallinity of perovskite on $\mathrm{NiO}$ was also improved compared to the that of formed on PEDOT:PSS. The number of grain boundaries was reduced with an increase in crystal size, leading to a decrease in the recombination process. These factors may affect the higher open circuit voltage in case of $\mathrm{NiO}$ than PEDOT:PSS. The thickness also changed the device efficiency as the thinner $\mathrm{NiO}$ film $(<40 \mathrm{~nm})$ showed current leakage and low shunt resistance, resulting in a low open-circuit voltage and fill factor. Perhaps in thinner films the coverage of $\mathrm{NiO}$ could be very low, while for thicker films $(120 \mathrm{~nm})$, the series resistance also seemed to be increasing, leading to a decrease in the fill factor. Thus, the optimized film with $80 \mathrm{~nm}$ thickness showed the best performance. The air stability of device in ambient environment without encapsulation with $\mathrm{NiO}$ as HTL remained good for 60 days, but the device with organic HTL started degrading only after 5 days [36]. Singh et al. applied $\mathrm{NiO}$ thin film as HTL in organic solar cell viaan inkjet printing technique. With device structure ITO/NiO(IJ)/P3HT:PC ${ }_{60} \mathrm{BM}(70 \mathrm{~nm}) / \mathrm{LiF}(1 \mathrm{~nm}) / \mathrm{Al}$ obtained maximum PCE of $\sim 2.60 \%$. Parameters such as AT, surface treatment, thickness of $\mathrm{NiO}$ thin film played key roles in optimization [37]. Loi developed a direct method of $\mathrm{NiO}$ film deposition from $\mathrm{NiO}$ nanopowder mixing with $\mathrm{HCl}$. He mainly optimized the $\mathrm{AT}$ of the $\mathrm{NiO}$ thin film with 350 , 400 , and $450{ }^{\circ} \mathrm{C}$ and the corresponding obtained PCE were $16.23,15.48$, and $14.18 \%$ respectively. The completed perovskite solar cell structures were FTO/PEDOT:PSS or $\mathrm{NiO}_{x} / \mathrm{MAPbI}_{3-x} \mathrm{Cl}_{x} / \mathrm{PCBM} / \mathrm{C}_{60}+\mathrm{C} / \mathrm{Ag}$ [12]. Electron beam physical vapor deposition (EBPVD) based $\mathrm{NiO} \mathrm{HTL}$ was incorporated into $\mathrm{FTO} / \mathrm{EBNiO} / \mathrm{CH}_{3} \mathrm{NH}_{3} \mathrm{PbI}_{3} / \mathrm{PCBM} / \mathrm{BCP}$ solar cell showed faster charge transfer and more effectively suppressed recombination and fewer surface trap states with a PCE of $10.80 \%$ [38]. Kim used polyethylene glycol (PEG)-assisted sol-gel synthesis of the compact NiO as HTL. There was a significant improvement in the uniformity and smoothness of the film morphology of the compact $\mathrm{NiO}$, which modified the interfacial properties between the layers. It helped in the good extraction of charge and suppression of charge recombination. He also incorporated PEDOT:PSS onto NiO layer as a hybrid HTL, which facilitated efficient cascade charge migration and passivation of the tiny pinholes. The introduction of compact NiO HTL improved the PCE from 5.68 to $6.91 \%$ and for the hybrid PEDOT:PSS and NiO HTL, PCE improved from 7.26 to $7.93 \%$. Thus, optimizing the interfacial properties also improved the overall PCE of the solar cells [39]. Akhtaruzzaman et al. used the EBPVD technique to synthesize $\mathrm{NiO}$ thin film and incorporated in PSC as HTL with structure glass/FTO/NiO ${ }_{x} / \mathrm{CH}_{3} \mathrm{NH}_{3} \mathrm{PbI}_{3} / \mathrm{PC}_{61} \mathrm{BM} / \mathrm{BCP} / \mathrm{Ag}$. There was a difference in PCE for the HTLs which was normal $\mathrm{NiO}$ and annealed $\mathrm{NiO}$ thin film as 13.20 and $13.24 \%$ respectively. Their optimized AT was $500{ }^{\circ} \mathrm{C}$ with a thickness of $18 \mathrm{~nm}$. There was a difference in degradation in efficiency with time for normal and annealed device. In ambient environment normal device retained $72.2 \%$ and annealed device retained $76.96 \%$ of the initial efficiency after 28 days of fabrication of the PSCs [40]. The comparative performance of the PSCs with NiO as HTL is given in Table 1. 
TABLE 1. Overall Performance of the PSCs with NiO as HTL based on SGSC method

\begin{tabular}{|c|c|c|c|c|c|}
\hline Device Configuration & $V_{o c}[\mathrm{~V}]$ & $J_{s c}\left[\mathrm{~mA} / \mathrm{cm}^{2}\right]$ & FF & PCE & Ref. \\
\hline $\mathrm{FTO} / \mathrm{NiO}_{x} / \mathrm{CH}_{3} \mathrm{NH}_{3} \mathrm{PbI}_{3} / \mathrm{C}_{60} / \mathrm{SnO}_{2} \mathrm{NCs} / \mathrm{Ag}$ & 1.12 & 23.7 & 0.76 & $18.8 \%$ & [41] \\
\hline $\begin{array}{c}\mathrm{ITO} / \mathrm{NiO} / \mathrm{Cs}_{0.05}\left(\mathrm{MA}_{0.17} \mathrm{FA}_{0.83}\right)_{0.95} \mathrm{~Pb}\left(\mathrm{I}_{0.9} \mathrm{Br}_{0.1}\right)_{3} / \\
\mathrm{PCBM} / \mathrm{ZnO} / \mathrm{Al}\end{array}$ & $1 / 023$ & $22 / 2$ & $0 / 82$ & $18.6 \%$ & [42] \\
\hline $\mathrm{ITO} / \mathrm{NiO} / \mathrm{CH}_{3} \mathrm{NH}_{3} \mathrm{PbI}_{3} / \mathrm{PCBM} / \mathrm{Ti}(\mathrm{Nb}) \mathrm{O}_{x} / \mathrm{Ag}$ & 1.07 & 21.88 & 0.79 & $18.49 \%$ & [43] \\
\hline $\mathrm{FTO} / \mathrm{NiO} / \mathrm{CH}_{3} \mathrm{NH}_{3} \mathrm{PbI}_{3} / \mathrm{PCBM} / \mathrm{BCP} / \mathrm{Ag}$ & 0.99 & 22.92 & 0.803 & $18.15 \%$ & [44] \\
\hline $\mathrm{ITO} / \mathrm{NiO} / \mathrm{CH}_{3} \mathrm{NH}_{3} \mathrm{PbI}_{3} / \mathrm{C}_{60} / \mathrm{Bis}_{-} \mathrm{C}_{60} / \mathrm{Ag}$ & 1.03 & 21.80 & 0.784 & $17.70 \%$ & [45] \\
\hline $\mathrm{FTO} / \mathrm{NiO} /$ Perovksite/PCBM/Bis-C 60 /Ag & 1.10 & 21.67 & 0.75 & $17.64 \%$ & [46] \\
\hline ITO/NiO/Perovskite/PCBM/PDINO/Ag & 1.11 & 20.57 & 0.765 & $17.5 \%$ & [47] \\
\hline $\mathrm{ITO} / \mathrm{NiO} / \mathrm{CH}_{3} \mathrm{NH}_{3} \mathrm{PbI}_{3} / \mathrm{PCBM} / \mathrm{Ag}$ & 1.04 & 23.51 & 0.69 & $16.91 \%$ & [48] \\
\hline $\mathrm{NiO}_{x} / \mathrm{MAPbI}_{3-x} \mathrm{Cl}_{x} / \mathrm{PCBM} / \mathrm{C}_{60}+\mathrm{C} / \mathrm{Ag}$ & 1.08 & 24.25 & 0.66 & $16.76 \%$ & [12] \\
\hline $\mathrm{ITO} / \mathrm{NiO} / \mathrm{CH}_{3} \mathrm{NH}_{3} \mathrm{PbI}_{3} / \mathrm{PCBM} / \mathrm{Ag}$ & 1.103 & 21.28 & 0.714 & $16.74 \%$ & [49] \\
\hline $\mathrm{TO} / \mathrm{NiO} / \mathrm{CH}_{3} \mathrm{NH}_{3} \mathrm{PbI}_{3} / \mathrm{PCBM} / \mathrm{Ag}$ & 1.09 & 19.9 & 0.769 & $16.68 \%$ & {$[50]$} \\
\hline $\mathrm{TO} / \mathrm{NiO} / \mathrm{CH}_{3} \mathrm{NH}_{3} \mathrm{PbI}_{3} / \mathrm{PCBM} / \mathrm{Ag}$ & 1.07 & 20.58 & 0.748 & $16.47 \%$ & [51] \\
\hline $\mathrm{ITO} / \mathrm{NiO}_{x} / \mathrm{CH}_{3} \mathrm{NH}_{3} \mathrm{PbI}_{3} / \mathrm{PCBM} / \mathrm{Al}$ & 1.01 & 21.0 & 0.76 & $14.5 \pm 1.6 \%$ & [36] \\
\hline $\mathrm{FTO} / \mathrm{NiO}_{x} / \mathrm{CH}_{3} \mathrm{NH}_{3} \mathrm{PbI}_{3} / \mathrm{PCBM} / \mathrm{BCP} / \mathrm{Ag}$ & 0.99 & 17.16 & 0.78 & $13.24 \%$ & [40] \\
\hline ITO/NiO/ $\mathrm{CH}_{3} \mathrm{NH}_{3} \mathrm{PbI}_{3-x} \mathrm{Cl}_{x} / \mathrm{PCBM} / \mathrm{BCP} / \mathrm{Al}$ & 0.92 & 12.43 & 0.68 & $7.80 \%$ & [52] \\
\hline ITO/NiO/P3HT:PCBM/Ca/Al & 0.58 & 8.6 & 0.66 & $3.60 \%$ & [16] \\
\hline ITO/NiO/P3HT/PCBM/Ca/Al & 0.58 & 10 & 0.58 & $3.38 \%$ & [17] \\
\hline ITO/NiO(IJ)/P3HT:PC ${ }_{60} \mathrm{BM} / \mathrm{LiF} / \mathrm{Al}$ & 0.60 & 8.57 & 0.50 & 2.60 & [37] \\
\hline
\end{tabular}

\section{Doping}

Improvement in the efficiency of the cell is the main concern, so doping of some metals into $\mathrm{NiO}$ was also applied to enhance the HTL property. Jung et al. incorporated $\mathrm{Cu}$ doped $\mathrm{NiO}$ in PSCs consisting of methylammonium lead halide perovskite. Synthesis via low temperature combustion method $\left(150{ }^{\circ} \mathrm{C}\right)$ and conventional solution based high temperature method $\left(500{ }^{\circ} \mathrm{C}\right)$ achieved the highest PCE of 17.8 and $15.52 \%$ respectively. ITO-free $\mathrm{Cu}-\mathrm{NiO}$ based PSC showed PCE of $13.42 \%$ [13]. Li doping in $\mathrm{NiO}$ thin film affected the grain size to decrease and variation in transmittance. Li doping also decreased the band gap but there was no such difference in crystallinity due to AT [53]. Addition of $\mathrm{Cu}$-dopant increased the grain size influencing the surface morphology and decrease in transmittance. The optical band gap value of the $\mathrm{Cu}$-doped $\mathrm{NiO}$ film $(3.69 \mathrm{eV})$ was lower than that of the undoped $\mathrm{NiO}$ film $(3.73 \mathrm{eV})$ and the resistivity of the $\mathrm{Cu}$-doped $\mathrm{NiO}$ film was $23 \Omega \cdot \mathrm{m}$, which was significantly lower than that of the undoped $\mathrm{NiO}$ film $(320 \Omega \cdot \mathrm{m})$ [54]. The doping effect has also been observed in conductivity at lower AT of $700{ }^{\circ} \mathrm{C}$ as increasing in conductivity [55]. Cs: $\mathrm{NiO}_{x}$ HTL achieved $16-19 \%$ PCE [56] and molecule F6TCNNQ dopingachieved PCE of $20.86 \%$ [57]. So, doping also enhanced the PCE of the PSCs. The comparative performance of the PSCs of doped $\mathrm{NiO}$ as HTL is given in Table 2.

\section{Conclusion}

The exploration of different properties of $\mathrm{NiO}$ nanoparticles and thin films led to the potential use in various applications. Incorporation of inorganic HTL showed a sound improvement in the overall performance of the PSCs. Different synthetic routes had its own advantages and disadvantages. The best route will be the one which is very cost effective and provides higher efficiency while leaving the other properties intact. Although the sol-gel method has its own limitations, it is very accessible for everyone. So, more improvement can be met using this method. The 
TABLE 2. Overall Performance of the PSCs with doped-NiO as HTL based on SGSC method

\begin{tabular}{|c|c|c|c|c|c|}
\hline Device Configuration & $V_{o c}[\mathrm{~V}]$ & $J_{s c}\left[\mathrm{~mA} / \mathrm{cm}^{-2}\right]$ & FF & PCE & Ref. \\
\hline $\begin{array}{c}\text { ITO/F6TCNNQ: } \mathrm{NiO}_{x} / \mathrm{CsFAMAperovskite/} \\
\text { PCBM/ZrAcac/Ag }\end{array}$ & 1.12 & 23.18 & 0.80 & $20.86 \%$ & [57] \\
\hline $\mathrm{ITO} / \mathrm{Cu}: \mathrm{NiO} / \mathrm{CH}_{3} \mathrm{NH}_{3} \mathrm{PbI}_{3} / \mathrm{C}_{60} / \mathrm{BCP} / \mathrm{Ag}$ & 1.12 & 22.28 & 0.81 & $20.26 \%$ & [57] \\
\hline 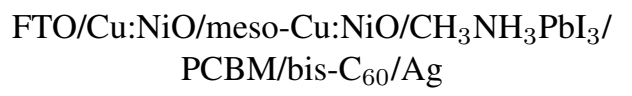 & 1.11 & 21.58 & 0.81 & $19.62 \%$ & [58] \\
\hline FTO/Cs: $\mathrm{NiO}_{x} / \mathrm{MAPbI}_{3} / \mathrm{PCBM} / \mathrm{ZrAcac} / \mathrm{Ag}$ & 1.12 & 21.77 & 0.79 & $19.35 \%$ & [56] \\
\hline ITO/Cu:NiO/ $\mathrm{CH}_{3} \mathrm{NH}_{3} \mathrm{PbI}_{3} / \mathrm{PCBM} / \mathrm{BCP} / \mathrm{Ag}$ & 1.11 & 20.76 & 0.81 & $18.66 \%$ & [59] \\
\hline ITO/Cu: $\mathrm{NiO} / \mathrm{CH}_{3} \mathrm{NH}_{3} \mathrm{PbI}_{3} / \mathrm{Bis} \mathrm{C}_{60} / \mathrm{C}_{60} / \mathrm{Ag}$ & 1.05 & 21.60 & 0.77 & $17.46 \%$ & [13] \\
\hline ITO/Li:NiO/CH${ }_{3} \mathrm{NH}_{3} \mathrm{PbI}_{3} / \mathrm{PCBM} / \mathrm{Ag}$ & 1.05 & 22.8 & 0.64 & $15.51 \%$ & [60] \\
\hline $\mathrm{FTO} / \mathrm{Cu}: \mathrm{NiO} / \mathrm{CH}_{3} \mathrm{NH}_{3} \mathrm{PbI}_{3} / \mathrm{PCBM} / \mathrm{Ag}$ & 1.11 & 18.75 & 0.72 & $14.98 \%$ & [61] \\
\hline $\mathrm{FTO} / \mathrm{LiCu}: \mathrm{NiO} / \mathrm{CH}_{3} \mathrm{NH}_{3} \mathrm{PbI}_{3} / \mathrm{PCBM} / \mathrm{Ag}$ & 0.965 & 20.28 & 0.71 & $14.04 \%$ & [62] \\
\hline
\end{tabular}

doping has also showed good improvement. In most of the findings, variation in annealing temperature was done for optimization. The SGSC method is very facile for low cost synthesis and can sustain good method for higher PCE of the PSCs in future also.

\section{Conflicts of interest}

The authors declare there is no conflict of interest.

\section{Acknowledgements}

This work was supported by Science \& Engineering Research Board (SERB), New Delhi, Sanction Order No. EEQ/2017/000435 dated 17 March, 2018.

\section{References}

[1] Fatet J. Recreating Edmond Becquerel's electrochemical actinometer. Arch. Des Sci., 2005, 58, P. 149-158.

[2] Timeline of solar cells, Wikipedia.org, 2013. URL: http://en.wikipedia.org/w/index.php?title=Timeline_of_solar_cells\&oldid=577975981.

[3] Bellis M. History and Definition of a Solar Cell. ThoughtCo, 2020, URL: thoughtco.com/history-of-solar-cells-1992435.

[4] N.R.E.L. (NREL), Best Research Efficiency, 2016, URL: https://www.nrel.gov/pv/cell-efficiency.html.

[5] Kour R., Arya S., et al. Potential Substitutes for Replacement of Lead in Perovskite Solar Cells: A Review, Glob. Challenges, 2019, 3, 1900050.

[6] Kojima A., Teshima K., Shirai Y.,, Miyasaka T. Organometal halide perovskites as visible-light sensitizers for photovoltaic cells. J. Am. Chem. Soc., 2009, 131, 6050-1.

[7] Kim H.S., Lee C.R., et al. Lead iodide perovskite sensitized all-solid-state submicron thin film mesoscopic solar cell with efficiency exceeding 9\%. Sci. Rep., 2012, 2, P. 1-7.

[8] Yin X., Guo Y., et al. Nickel Oxide as Efficient Hole Transport Materials for Perovskite Solar Cells. Sol. RRL, 2019,3 , P. 1-27.

[9] Ningsih S.K.W. Effect of various solvent on the synthesis of nio nanopowders by simple sol-gel methods and its characterization. Indones. J. Chem., 2015, 15, P. 50-55.

[10] Jlassi M., Sta I., Hajji M., Ezzaouia H. Optical and electrical properties of nickel oxide thin films synthesized by sol-gel spin coating. Mater. Sci. Semicond. Process, 2014, 21, P. 7-13.

[11] Sahoo P., Thangavel R. Effect of annealing temperature on physical properties of solution processed nickel oxide thin films. AIP Conf. Proc., 2018, 1961 (1), 030041.

[12] Loi Nguyen. New Method of Nickel Oxide as Hole Transport Layer and Characteristics of Nickel Oxide Based Perovskite Solar Cell. ProQuest Dissertations And Theses, 2018, 57-06, 59 p.

[13] Jung J.W., Chueh C.C., Jen A.K.Y. A Low-Temperature, Solution-Processable, Cu-Doped Nickel Oxide Hole-Transporting Layer via the Combustion Method for High-Performance Thin-Film Perovskite Solar Cells. Adv. Mater., 2015, 27, P. 7874-7880.

[14] Wu M.S., Yang C.H., Wang M.J. Morphological and structural studies of nanoporous nickel oxide films fabricated by anodic electrochemical deposition techniques. Electrochim. Acta, 2008, 54, P. 155-161.

[15] Zhao Y., Wang H., et al. Structures, electrical and optical properties of nickel oxide films by radio frequency magnetron sputtering. Vacuum, 2014, 103, P. 14-16.

[16] Steirer K.X., Chesin J.P., et al. Olson, Solution deposited NiO thin-films as hole transport layers in organic photovoltaics. I , 2010, 11, P. 1414-1418.

[17] Hsu C.C., Su H.W., et al. Atomic layer deposition of NiO hole-transporting layers for polymer solar cells. Nanotechnology, 2015 , 26, 385201. 
[18] Zaouche C., Aoun Y., Benramache S., Gahtar A. Synthesis and Characterization of Deposited NiO Thin Films by Spray Pyrolysis Technique. Sci. Bull. Valahia Univ. - Mater. Mech., 2020, 17, P. 27-32.

[19] Jeevanandam P., Pulimi V.R.R. Synthesis of nanocrystalline $\mathrm{NiO}$ by sol-gel and homogeneous precipitation methods. Indian J. Chem. - Sect. A Inorganic, Phys. Theor. Anal. Chem., 2012, 51, P. 586-590.

[20] Soonmin H. Preparation and characterization of nickel oxide thin films: A review. Int. J. Appl. Chem., 2016, 12, P. 87-93.

[21] Ukoba K.O., Eloka-Eboka A.C., Inambao F.L. Review of nanostructured NiO thin film deposition using the spray pyrolysis technique. Renew. Sustain. Energy Rev., 2018, 82, P. 2900-2915.

[22] Zhang P.P., Zhou Z.J., Kou D.X., Wu S.X. Perovskite Thin Film Solar Cells Based on Inorganic Hole Conducting Materials. Int. J. Photoenergy, 2017, 2017, 6109092.

[23] Jiménez-González A.E., Cambray J.G. Deposition of $\mathrm{NiO}_{x}$ thin films by sol-gel technique. Surf. Eng., 2000, 16, P. 73-76.

[24] Korošec R.C., Bukovec P. Sol-Gel Prepared NiO Thin Films for electrochromic applications. Acta Chim. Slov., 2006, 53 (2), P. $136-147$.

[25] Chavan U.J., Yadav A.A. Structural, Optical and Electrical Properties of Chemical Bath Deposited NiO Thin Films. Int. J. of Engineering Sciences \& Research Technology, 2016, 5 (10), P. 282-287.

[26] Ghodsi F.E., Khayatiyan S.A. Preparation and determination of optical properties of NiO thin films deposited by DIP coating technique. Surf. Rev. Lett., 2007, 14, P. 219-224.

[27] Al-Ghamdi A.A., Mahmoud W.E., Yaghmour S.J., Al-Marzouki F.M. Structure and optical properties of nanocrystalline NiO thin film synthesized by sol-gel spin-coating method. J. Alloys Compd., 2009, 486, P. 9-13.

[28] Patil V.P., Pawar S., et al. Effect of Annealing on Structural, Morphological, Electrical and Optical Studies of Nickel Oxide Thin Films. J. Surf. Eng. Mater. Adv. Technol., 2011, 01, P. 35-41.

[29] Nalage S.R., Chougule M.A., et al. Sol-gel synthesis of nickel oxide thin films and their characterization. Thin Solid Films, 2012, 520, P. 4835-4840

[30] Zorkipli N.N.M., Kaus N.H.M., Mohamad A.A. Synthesis of NiO Nanoparticles through Sol-gel Method. Procedia Chem., 2016, 19, P. 626631.

[31] Abdullah M.A.R., Mamat M.H., et al. Preparation of nickel oxide thin films at different annealing temperature by sol-gel spin coating method. AIP Conf. Proc., 2016, 1733, 020013.

[32] Kayani Z.N., Butt M.Z., Riaz S., Naseem S. Synthesis of NiO nanoparticles by sol-gel technique. Mater. Sci. Pol., 2018, 36, P. 547-552.

[33] Benramache S., Aoun Y., Arif A. The film thickness effect on the physical properties of NiO thin films elaborated by Sol-gel method. J. Sci. Technol., 2020, 12, P. 7-14.

[34] Aswathy N.R., Varghese J., Vinodkumar R. Effect of annealing temperature on the structural, optical, magnetic and electrochemical properties of $\mathrm{NiO}$ thin films prepared by sol-gel spin coating. J. Mater. Sci. Mater. Electron., 2020, 31, P. 16634-16648.

[35] Irwin M.D., Servaites J.D., et al. Structural and electrical functionality of $\mathrm{NiO}$ interfacial films in bulk heterojunction organic solar cells. Chem. Mater, 2011, 23, P. 2218-2226.

[36] You J., Meng L., et al. Improved air stability of perovskite solar cells via solution-processed metal oxide transport layers. Nat. Nanotechnol., 2016, 11, P. 75-81.

[37] Singh A., Gupta S.K., Garg A. Inkjet printing of NiO films and integration as hole transporting layers in polymer solar cells. Sci. Rep., 2017, 7, P. 1-12.

[38] Mahmud Hasan A.K., Jamal M.S., et al. Integration of NiO Layer as Hole Transport Material in Perovskite Solar Cells. Int. Conf. Sp. Sci. Commun. Iconsp., 2019, P. 267-270.

[39] Kim J.K. PEG-assisted sol-gel synthesis of compact nickel oxide hole-selective layer with modified interfacial properties for organic solar cells. Polymers (Basel), 2019, 11, P. 1-8.

[40] Akhtaruzzaman M., Hasan A.K.M., et al. Air-Stable Perovskite Photovoltaic Cells with Low Temperature Deposited $\mathrm{NiO}_{x}$ as Efficient HoleTransporting Material. Opt. Mater. Express, 2020, 10, P. 1801-1816.

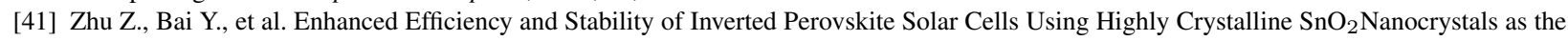
Robust Electron-Transporting Layer. Adv. Mater, 2016, 28, P. 6478-6484.

[42] Najafi M., Di Giacomo F., et al. Highly Efficient and Stable Flexible Perovskite Solar Cells with Metal Oxides Nanoparticle Charge Extraction Layers. Small, 2018, 14, P. 1-10.

[43] He J., Bi E., et al. Ligand-Free, Highly Dispersed $\mathrm{NiO}_{x}$ Nanocrystal for Efficient, Stable, Low-Temperature Processable Perovskite Solar Cells. Sol. RRL, 2018, 2, P. 1-7.

[44] Tang L.J., Chen X., et al. A Solution-Processed Transparent NiO Hole-Extraction Layer for High-Performance Inverted Perovskite Solar Cells. Chem. - A Eur. J., 2018, 24, P. 2845-2849.

[45] Zhang H., Cheng J., et al. Pinhole-free and surface-nanostructured niox film by room-Temperature solution process for high-performance flexible perovskite solar cells with good stability and reproducibility. ACS Nano, 2016, 10, 1503-1511.

[46] Vinet L., Zhedanov A. A “missing” family of classical orthogonal polynomials. J. Phys. A Math. Theor., 2011, 44, P. 1689-1699.

[47] Hou Y., Chen W., et al. Overcoming the Interface Losses in Planar Heterojunction Perovskite-Based Solar Cells. Adv. Mater, 2016, 28, P. 5112-5120.

[48] Guo X., Luo G., et al. A $16.5 \%$ efficient perovskite solar cells with inorganic NiO film as hole transport material. IEEE J. Photovoltaics, 2018, 8, P. 1039-1043.

[49] Yoon S., Kang D.W. Solution-processed nickel oxide hole transport layer for highly efficient perovskite-based photovoltaics. Ceram. Int., 2018, 44, P. 9347-9352.

[50] Yin X., Liu J., et al. Solvothermal derived crystalline $\mathrm{NiO}_{x}$ nanoparticles for high performance perovskite solar cells. J. Power Sources, 2016, 329, P. 398-405.

[51] Yin X., Chen P., et al. Highly Efficient Flexible Perovskite Solar Cells Using Solution-Derived $\mathrm{NiO}_{x}$ Hole Contacts. ACS Nano, 2016, 10, P. 3630-3636.

[52] Jeng J.Y., Chen K.C., et al. Nickel oxide electrode interlayer in $\mathrm{CH}_{3} \mathrm{NH}_{3} \mathrm{PbI}_{3}$ perovskite/PCBM planar-heterojunction hybrid solar cells. Adv. Mater, 2014, 26, P. 4107-4113.

[53] Jesuraj S.A., Haris M., Immanuel P. Structural and Optical Properties of Pure NiO and Li-Doped Nickel Oxide Thin Films by Sol-Gel Spin Coating Method. Int. J. Sci. Res., 2014, P. 8-9. 
[54] Kim K.H., Takahashi C., Abe Y., Kawamura M. Effects of Cu doping on nickel oxide thin film prepared by sol-gel solution process. Optik (Stuttg), 2014, 125, P. 2899-2901.

[55] Ehara T., Sasaki K., Abe M., Nakanishi T. Preparation of copper-doped nickel oxide thin films by sol-gel method using nickel and copper acetate. Mater. Sci. Forum, 2017, 909, P. 213-218.

[56] Chen W., Liu F.Z., et al. Cesium Doped $\mathrm{NiO}_{x}$ as an Efficient Hole Extraction Layer for Inverted Planar Perovskite Solar Cells. Adv. Energy Mater., 2017, 7, P. 1-8.

[57] Chen W., Zhou Y., et al. Molecule-Doped Nickel Oxide: Verified Charge Transfer and Planar Inverted Mixed Cation Perovskite Solar Cell. Adv. Mater., 2018, 30, P. 1-9.

[58] Yao K., Li F., et al. A copper-doped nickel oxide bilayer for enhancing efficiency and stability of hysteresis-free inverted mesoporous perovskite solar cells. Nano Energy, 2017, 40, P. 155-162.

[59] He Q., Yao K., et al. Room-Temperature and Solution-Processable Cu-Doped Nickel Oxide Nanoparticles for Efficient Hole-Transport Layers of Flexible Large-Area Perovskite Solar Cells. ACS Appl. Mater. Interfaces, 2017, 9, P. 41887-41897.

[60] Qiu Z., Gong H., et al. Enhanced physical properties of pulsed laser deposited NiO films via annealing and lithium doping for improving perovskite solar cell efficiency. J. Mater. Chem. C, 2017, 5, P. 7084-7094.

[61] Kim J.H., Liang P.W., et al. High-performance and environmentally stable planar heterojunction perovskite solar cells based on a solutionprocessed copper-doped nickel oxide hole-transporting layer. Adv. Mater., 2015, 27, P. 695-701.

[62] Liu M.-H., Zhou Z.-J., et al. P-type Li, Cu-codoped $\mathrm{NiO}_{x}$ hole-transporting layer for efficient planar perovskite solar cells. Opt. Express, 2016, 24, A1349. 